\title{
高濃度の浮遊砂を含有した 流体の粘度の測定とその評価
}

\author{
中村 友昭 1 - 鈴木 愛美 2 - 水谷 法美 3 \\ 1 正会員 名古屋大学准教授 大学院工学研究科社会基盤工学専攻（ \\ E-mail: tnakamura@nagoya-u.jp \\ 2 学生会員 名古屋大学大学院工学研究科社会基盤工学専攻（广464-8603 名古屋市千種区不老町） \\ E-mail: suzuki.manami@c.mbox.nagoya-u.ac.jp \\ 3 フェロー 名古屋大学教授 大学院工学研究科社会基盤工学専攻（广464-8603 名古屋市千種区不老町） \\ E-mail: mizutani@civil.nagoya-u.ac.jp
}

\begin{abstract}
濁水状態の津波・海岸保全施設本体の挙動・基礎地盤の洗掘等の地形変化・基礎地盤の支持力の 4 者間 の相互作用を解析できる数值計算モデルの構築に向けた基礎的な研究として, 本研究では浮遊砂を含むこ とによる粘度の変化を取り扱い，その評価式のパラメータの同定を，粘度計を用いた実験により行った。 その結果，浮遊砂を含まない清水状態のときは，粘度がせん断応力によらないニュートン流体であった一 方で，浮遊砂を含んだ濁水状態のときには，粘度はせん断応力の増加とともに減少し，非ニュートン流体 となることを確認した。また，浮遊砂濃度が与えられれば第 1 ニュートン領域での低せん断ニュートン粘 度が推定でき，さらにその低せん断ニュートン粘度を用いることでせん断応力が与えられれば浮遊砂を含 む流体の粘度が推定できることを示した。
\end{abstract}

Key Words : viscosity, suspended sediment, shear stress, non-Newtonian fluid, viscometer

\section{1. 緒言}

東北地方太平洋沖地震津波による被災地の復興や，南 海トラフ等の巨大地震に伴う津波に対する減災のために, 海岸保全施設の津波による被災機構とその効果を粘り強 く発揮できる構造についての検討が行われてきている. しかし，津波・海岸保全施設本体の挙動・基礎地盤の洗 掘等の地形変化・基礎地盤の支持力の相互作用を解析で きる数值計算モデルは限られており，上述した研究の多 くは水理実験による検討に留まっている.

一方，東北地方太平洋沖地震時に見られたように，遡 上津波は底質を多く巻き込んだ濁水状態となっていると 推測される.このように浮遊砂を含んだ流れの構造は清 水流のそれとは異なるとVanoni ${ }^{1}$ によって指摘され, 定常 流に対して主にKármán定数の減少²) Darcy-Weisbachの 抵抗係数の減少 ${ }^{3)}$ の観点から検討が行われてきた。 これ については, 中川・辻本年が詳しい. ただし，上述した 海岸保全施設に対する既往の検討では浮遊砂を含まない 清水状態の津波を作用させていると思われ，津波力等に 対する評価が適切に行えていない可能性が考えられる. また，濁水状態であることがその評価に与える影響を検 討する際には，非定常な現象である津波に対しては数值 解析による検討が有用と考えられる.
そこで，濁水状態の津波・海岸保全施設本体の挙動・ 基礎地盤の洗掘等の地形変化・基礎地盤の支持力の相互 作用を解析できる数值計算モデルの構築に向けて, 浮遊 砂を含むことによる流れの構造の変化，すなわち密度と 粘度の変化を考慮できるように，本研究ではそのうち粘 度の変化に着目し，数值計算モデルに組み込むための粘 度の評価式に含まれるパラメータの同定を行う。

\section{2. 粘度のモデル化}

浮遊砂のような微粒子が懸濁している流体（以下，懸 濁液と呼ぶ) は非ニュートン特性を示し, 粘度 (粘性率, 粘性係数) $\mu$ は浮遊砂濃度, せん断応力, 温度, 微粒子 を構成する鉱物等の影響を受ける5).

粘度 $\mu$ の粒子濃度依存性に関して，粒子濃度として懸 濁液の体積に対する粒子の体積（体積比）を $\phi$, 溶媒の 粘度を $\mu_{w}$ としたとき, Einstein ${ }^{6}$ は理論解

$$
\mu=\mu_{w}(1+2.5 \phi)
$$

を導出している．また，より高濃度まで適用できるよう 上式を一般化した式として, Bathchelor ${ }^{7)}$ は2粒子間の相互 作用から次に示寸理論解を導いている. 


$$
\mu=\mu_{w}\left(1+2.5 \phi+6.2 \phi^{2}\right)
$$

さらに高濃度領域まで適用できる式として, Krieger・ Dougherty ${ }^{8}$ は次に示す半理論式を導いている.

$$
\mu=\mu_{w}\left(1-\frac{\phi}{\phi_{m}}\right)^{-[\mu] \phi_{m}}
$$

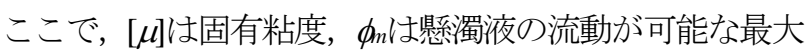
濃度であり, 均一径の剛体球粒子の懸濁液のとき $[\mu]=2.5$, $\phi_{m} \approx 0.6$ となる.ただし，この式は精度が良くないことか ら9), 実験式として以下が提案されている.

$$
\mu=\mu_{w}\left(1-\frac{\phi}{k}\right)^{-2}
$$

ここでkは定数であり, 直径76 $\pm 2 \mathrm{~nm}$ のシカを含むシク ロヘキサンの懸濁液の場合, 後述する低せん断ニュート ン粘度 $\mu$ に対して $k=0.63$, 高せん断ニュートン粘度 $\mu_{H}$ に

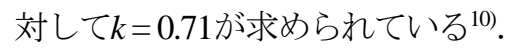

続いて，図-1に粘度 $\mu$ のせん断応力依存性の概念困 ${ }^{9}$ を 示す.ここで, てはせん断応力である. 図-1に示すように, せん断応力が小さい方から順に，まず領域孜第1二ュー トン領域では，懸濁液中の粒子構造がほとんど破壊され ないため, 粘度が高く一定值となる二ュートン流体の性 質を示す. 次の領域II擬塑性領域では, せん断応力に よる力と粒子の構造形成力が釣り合うところまで構造が 破壊されるため, 粘度が低下する擬塑性流体（指数関数 流体）の性質を示す. 続いて, 領域IIIの第2ニュートン領 域では，破壊できる構造はすべて破壊され層状構造で流 動するため, 粘度が変化しなくなるニュートン流体の性 質を示す. 最後に, 領域IVのダイラタント領域では, 層 状構造で安定に流れることができなくなり, 粘度が増加 するダイラタント流体の性質を示す．ここで，低せん断 ニュートン粘度と呼ばれる第1二ュートン領域での粘度 を $\mu$, 高せん断二ュートン粘度と呼ばれる第 2 ニュートン 領域での粘度を $\mu$ とししとき, 上記の領域のうち第1二 ユートン領域から第2ニュートン領域に対して

$$
\frac{\mu-\mu_{H}}{\mu_{L}-\mu_{H}}=\left[1+\left(\frac{\tau}{\tau_{c}}\right)^{n}\right]^{-1}
$$

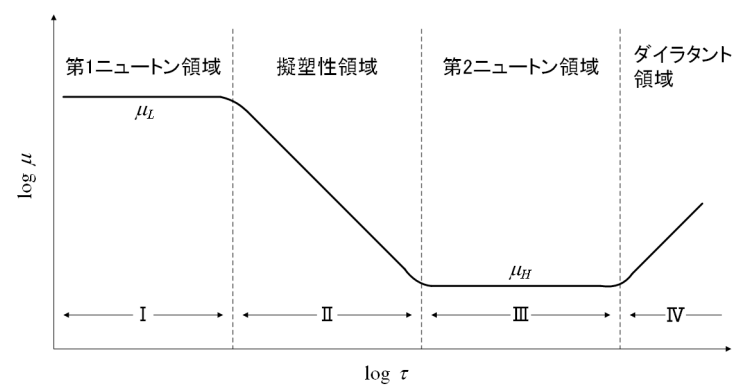

図-1 粘度 $\mu$ のせん断応力依存性 ${ }^{9}$

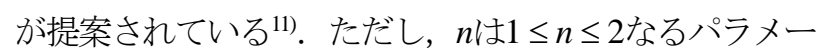
タであり, Krieger・Dougherty ${ }^{8)}$ はn=1としている. また, $a$ を粒子の半径, $k b$ をBoltzmann定数 $\left(=1.38054 \times 10^{-23} \mathrm{~J} / \mathrm{K}\right)$, Tを絶対温度， $\beta$ を $0.05 \leq \beta \leq 0.35$ なるパラメータとしたと き， $\tau_{c}$ は $\tau_{c}=k b T /\left(\beta a^{3}\right)$ と表される.

粒子として浮遊砂を対象とした研究に関して, 浮遊砂 濃度として懸濁液の体積に対する浮遊砂の質量(質量比) をC $\left(=\phi / \rho_{s}\right)$ としたとき，Krone ${ }^{12)}$ は

$$
\mu=\mu_{w} \exp \left(k_{f} C\right)
$$

に対して毛細管粘度計による実験結果からパラメータ $k_{f}$ の同定を行っている. ここで， $\rho$ は浮遊砂粒子の密度で ある.このように, 粘度 $\mu$ の浮遊砂濃度依存性を検討し

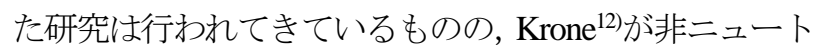
ン流体の測定に適していない毛細管粘度計を用いている ように, せん断応力依存性を検討した研究は見受けられ ない，そこで，粘度 $\mu$ の浮遊砂濃度依存性だけではなく せん断応力依存性も考慮した評価式の提案を行うために, 以下では式(4)のより一般的な形である式(3)の姉おび $[\mu]$ と，式(5)の $\mu_{L}, \mu_{H}, \tau_{c}, n の$ 同定を行う.

\section{3. 実験装置および実験条件}

写真-1に示すTVB-15型粘度計, 低粘度アダプタ, 高精 度低温循環恒温槽ビスコメイトVM-150F（東機産業製） を用いて粘度の測定を行った。

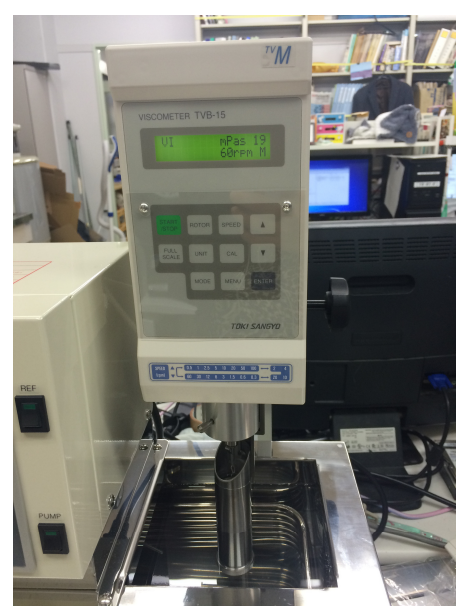

写真-1 TVB-15 型粘度計

表-1 実験条件

\begin{tabular}{cccc}
\hline 浮遊砂濃度 $\phi$ & 回転速度 $[\mathrm{rpm}]$ & 温度 $\left[{ }^{\circ} \mathrm{C}\right]$ & 測定回数 \\
\hline 0 & $12,30,60$ & 20 & 3 \\
\hline 0.03 & $12,30,60$ & 20 & 3 \\
\hline 0.05 & $6,12,30,60$ & 20 & 3 \\
\hline 0.08 & $3,6,12,30,60$ & 20 & 3 \\
\hline 0.10 & $3,6,12,30,60$ & 20 & 3 \\
\hline 0.15 & $3,6,12,30,60$ & 20 & 3 \\
\hline 0.20 & $3,6,12,30$ & 20 & 3 \\
\hline
\end{tabular}




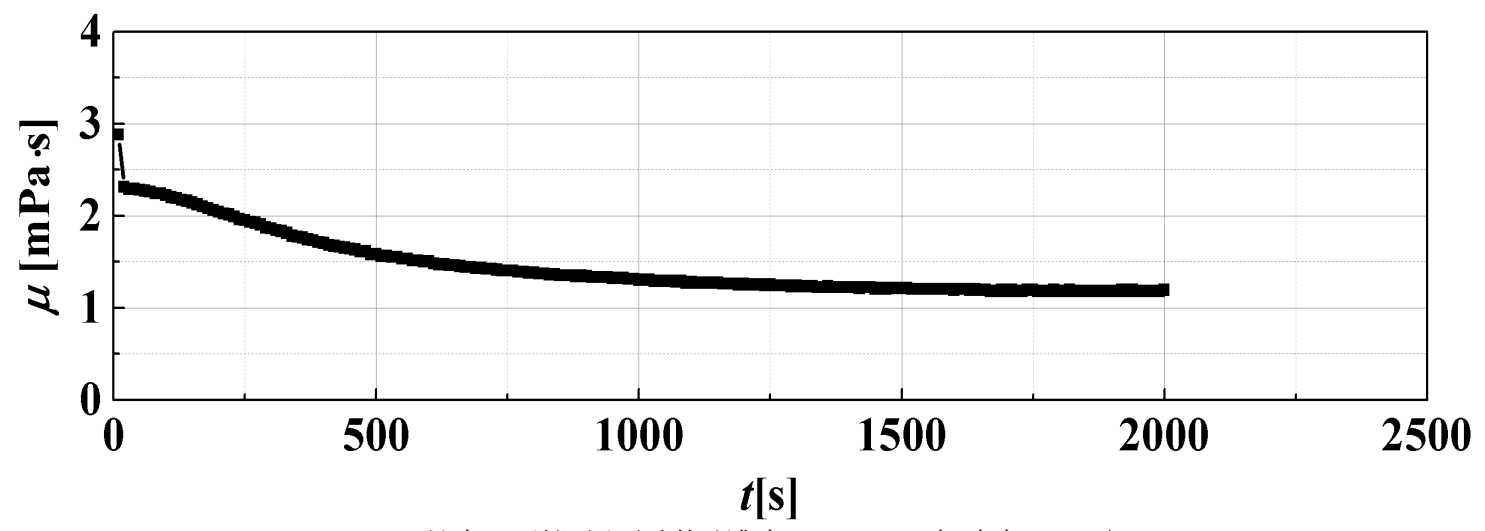

図-2 粘度 $\mu$ の計測例（浮遊砂濃度 $\phi=0.10$, 回転速度 $60 \mathrm{rpm}$ )

濁水状態を想定した測定液として，溶媒が水，溶質が 粘土（カオリン）の懸濁液を用いた。そして，表-1に示 す条件下で計測を行った。具体的には，測定液の温度を 恒温槽により $20{ }^{\circ} \mathrm{C} の 一$ 定とし, 浮遊砂濃度（体積比） $\phi$ を0.0，0.03，0.05，0.08，0.10，0.15，0.20の清水状態 $(\phi=$ 0)を含む7パターン，粘度計の回転速度を $3 ， 6 ， 12 ， 30$, $60 \mathrm{rpm}$ のパターン変化させた計29ケースの実験を行っ た. なお, 回転速度が遅い60 rpm以外のケースでは, 粘 土の沈殿を抑えるために最初の30秒間を60 rpmにし，そ の後所定の回転速度にした. 各ケースでは, 粘度の值を5 秒間隔でパソコンに取り込んだ。また，再現性を確認す るために，各ケースとも3回の測定を行った.

図-2に浮遊砂濃度 $\phi=0.10$, 回転速度 $60 \mathrm{rpm}$ のときの予 備実験の結果を例示する.ここで, 口印は5秒間隔の計測 值を表す，図-2より，計測開始直後の粘度 $\mu$ は5秒後以降 のそれと比較して大きく，異常な值を示していることが 分かる. また，その後しばらくは粘度 $\mu$ が比較的安定し た值となっているものの, 時間の経過とともに緩やかに 減少し, $20^{\circ} \mathrm{C}$ ときの水の粘度 $(1.00 \mathrm{mPa} \cdot \mathrm{s})$ に漸近して いる.これは, 粘土が沈降し清水状態に近づいたためと 考えられる，そこで，異常值後の15秒間の平均值をその 回の粘度とし,さらに3回分の粘度のデータを平均した值 をその測定液の粘度 $\mu$ とした。

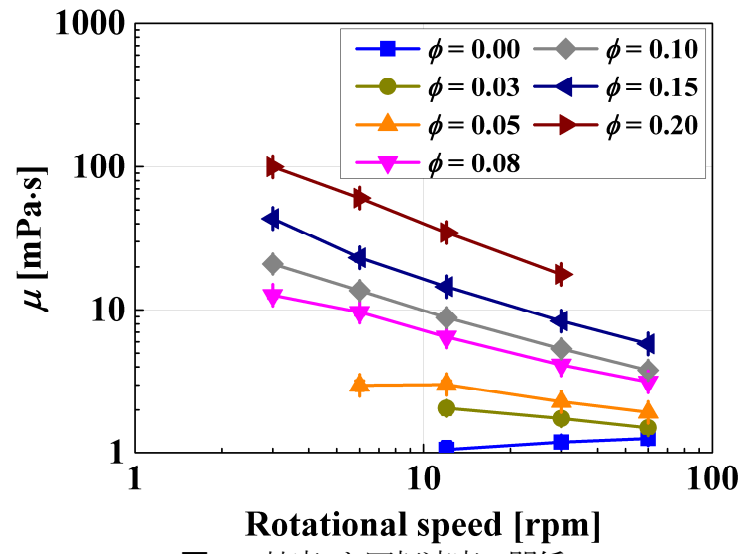

図-3 粘度 $\mu$ と回転速度の関係

\section{4. 実験結果および考察}

図-3に粘度 $\mu$ と回転速度の関係を示寸，同図より, 粘土 を含まない清水状態 $(\phi=0)$ のとき, 粘度 $\mu$ は回転速度によ らずほぼ一定值となっており，ニュートン流体となって いることが分かる，一方，粘土を含んだ濁水状態 $(\phi>0)$ のとき, 浮遊砂濃度 $\phi$ が等しい条件では，回転速度の増 加とともに粘度 $\mu$ が減少寸る傾向が確認でき, 粘土を含 んだことで非ニュートン流体となったことが分かる。さ らに, 回転速度が等しい条件では, 浮遊砂濃度 とともに粘度 $\mu$ が増加する傾向も確認できる.

続いて, 粘度 $\mu$ のせん断応力依存性を調べるため, 次 式により回転速度 $N$ をせん断応力て飞変換する.

$$
\tau=\mu D=\mu K_{2} N
$$

ここで，Dはずり速度 (せん断速度)，K2はずり速度係数 であり，今回使用した粘度計および低粘度アダプタの場 合は $K_{2}=1.193 \mathrm{~s}^{-1}$ である.

図-4から図-9に各浮遊砂濃度 $\phi$ に対する粘度 $\mu$ とせん断 応力ての関係を示す。ここで，喵は実験結果を表す。 な お，実線の説明は後述する，図-4から図-9より，浮遊砂 濃度фに関わらずせん断応力 $\tau の$ 増加とともに粘度 $\mu$ が減 少しており，図-3と類似した傾向が確認できる.

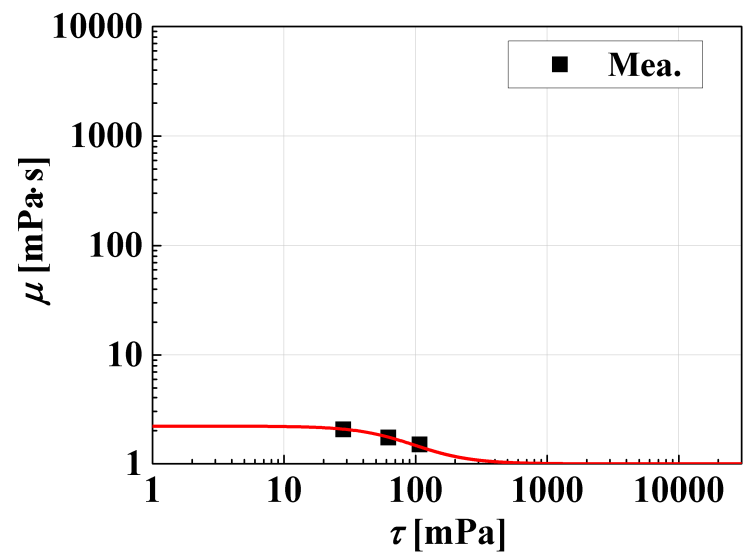

図-4 粘度 $\mu$ とせん断応力 $\tau の$ 関係（浮遊砂濃度 $\phi=0.03 ）$ 


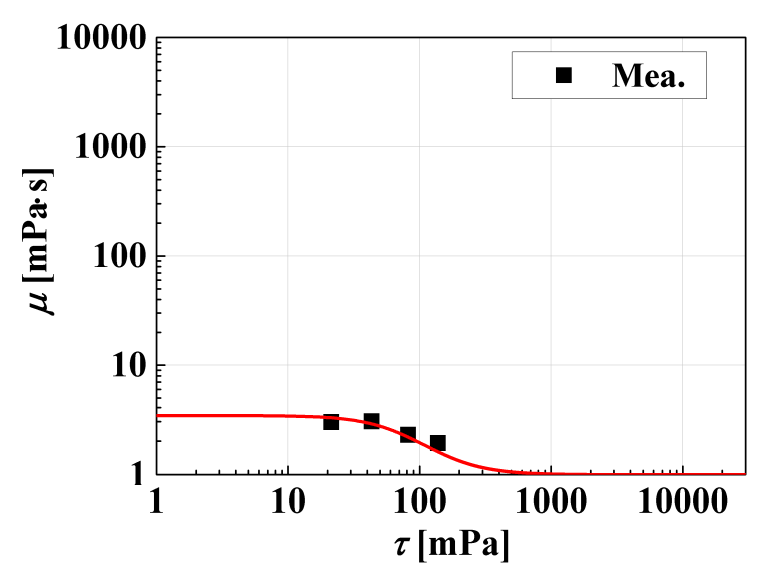

図-5 粘度 $\mu$ とせん断応力 $\tau$ の関係（浮遊砂濃度 $\phi=0.05 ）$

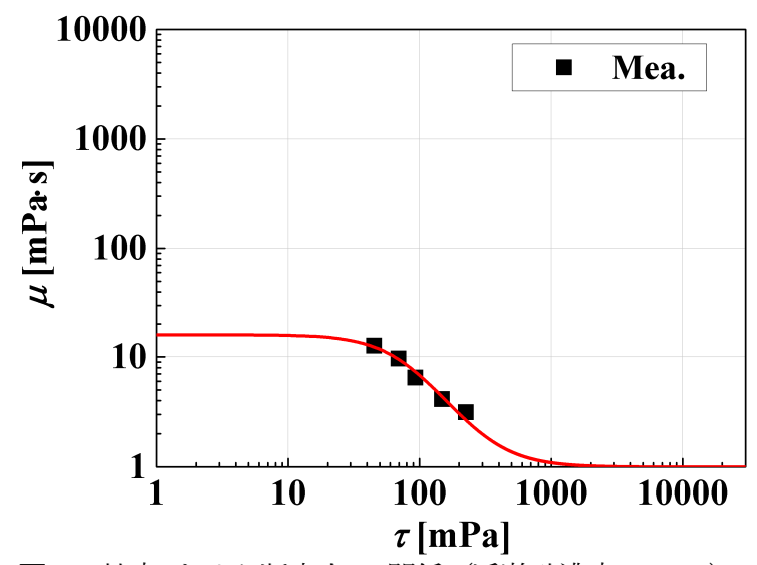

図-6 粘度 $\mu$ とせん断応力 $\tau$ の関係（浮遊砂濃度 $\phi=0.08 ）$

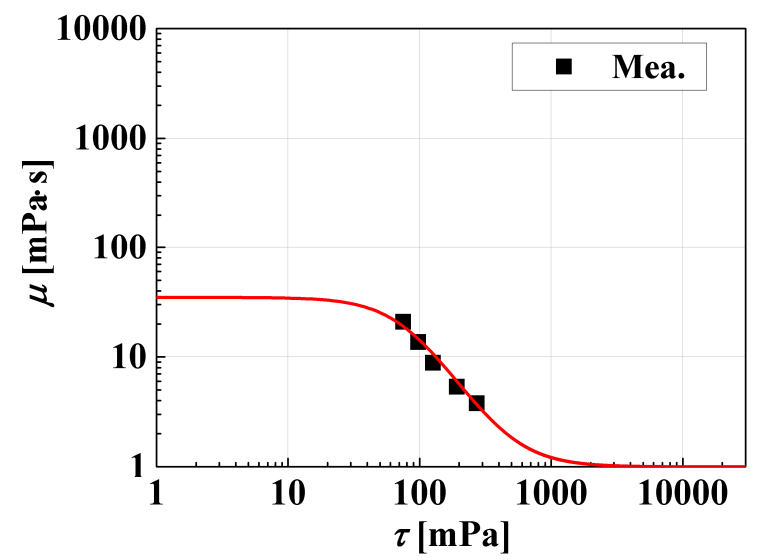

図-7 粘度 $\mu$ とせん断応力 $\tau の$ 関係（浮遊砂濃度 $\phi=0.10 ）$

図-4から図-9に示したデータに基づいて，式(5)の $\mu$, $\mu_{H}, \tau_{c}, n$ の同定を行う. 今回使用した粘度計では回転速 度を60 rpmより大きい值に設定できず，図-4から図-9よ り分かるように，高せん断領域で粘度 $\mu$ が一定になる領 域,つまり第2ニュートン領域の計測まではできず, 高せ ん断ニュートン粘度 $\mu_{H}$ を決定できなかった．そこで，せ 几断応力 $\tau$ の増加とともに粘度 $\mu$ が減少する傾向が確認 できていることから，高せん断領域では水の粘度に漸近 するものと考え，高せん断ニュートン粘度 $\mu_{H}$ を 1.00 $\mathrm{mPa} \cdot \mathrm{s}$ と仮定した. 次に, $\mu_{H}=1.00 \mathrm{mPa} \cdot \mathrm{s}$ としたとき, 1 $\leq n \leq 2 の$ 範囲で $\mu$ L， $\tau_{c} ， n$ をMathematicaを用いて最小自乗

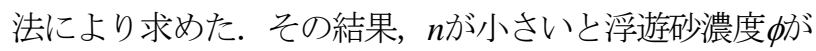

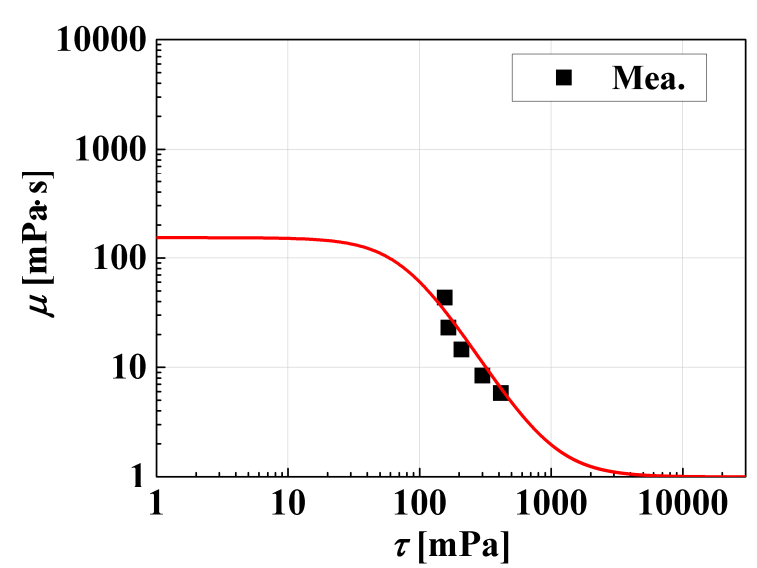

図-8 粘度 $\mu$ とせん断応力 $\tau$ の関係（浮遊砂濃度 $\phi=0.15 ）$

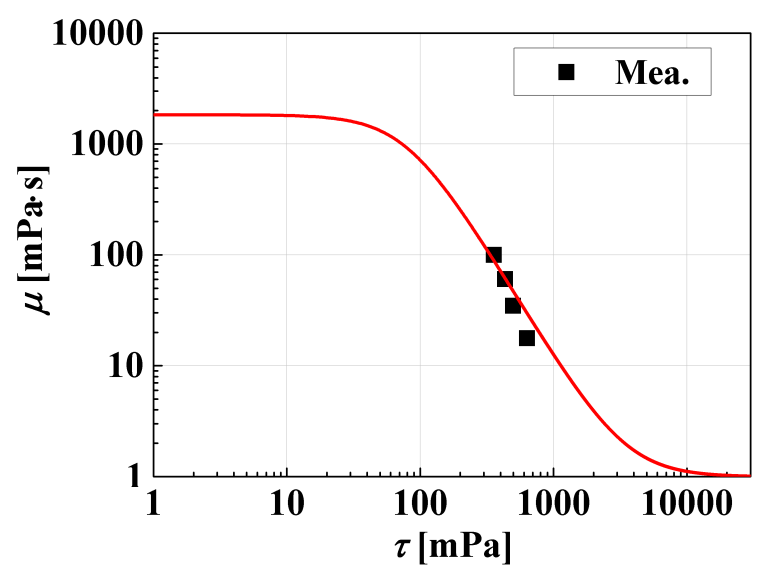

図-9 粘度 $\mu$ とせん断応力 $\tau$ の関係（浮遊砂濃度 $\phi=0.20 ）$

表-2 浮遊砂濃度 $\phi$ と低せん断ニュートン粘度 $\mu$ の関係

\begin{tabular}{cc}
\hline$\phi$ & $\mu_{\mathrm{L}}[\mathrm{mPa} \cdot \mathrm{s}]$ \\
\hline 0.03 & 2.20 \\
0.05 & 3.41 \\
0.08 & $1.59 \times 10$ \\
0.10 & $3.49 \times 10$ \\
0.15 & $1.53 \times 10^{2}$ \\
0.20 & $1.83 \times 10^{3}$ \\
\hline
\end{tabular}

高い場合に解が収束しないことが分かった．そのため,

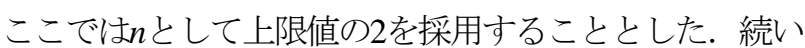
て, $\mu_{H}=1.00 \mathrm{mPa} \cdot \mathrm{s}, n=2$ としたとき，上記と同様に $\mu$

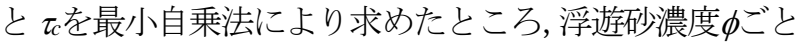
に $\mu_{\mathrm{L}} や \tau_{c}$ が異なる結果を得た。ここで，上述した $\tau_{c}=k_{b} T /$

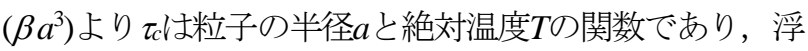
遊砂濃度功関数ではないことから，ここでは得られた の值を平均し $80 \mathrm{mPa}$ とすることとした. なお， Metha ${ }^{5)}$ りカオリンの半径 $a$ は0.05〜2 $\mu \mathrm{m}$ であることから, 例えば $a=1 \mu \mathrm{m}$ とすると， $\beta=0.0506$ となり上述した $0.05 \leq \beta \leq$ $0.35 の$ 範囲内に収まる. 最後に, $\mu_{H}=1.00 \mathrm{mPa} \cdot \mathrm{s}, n=2$, $\tau_{c}=80 \mathrm{mPa}$ としたとき，低せん断ニュートン粘度 $\mu_{\mathrm{L}}$ を最 小自乗法により求めた.

以上の結果を図-4から図-9の実線と表-2に示す. 図-4 から図-9より, 浮遊砂濃度 $\phi$ 高い条件では実験結果との 若干のずれが確認できるものの，実験結果を概ね評価で きていることが分かる. また，表-2に示すように，浮遊 


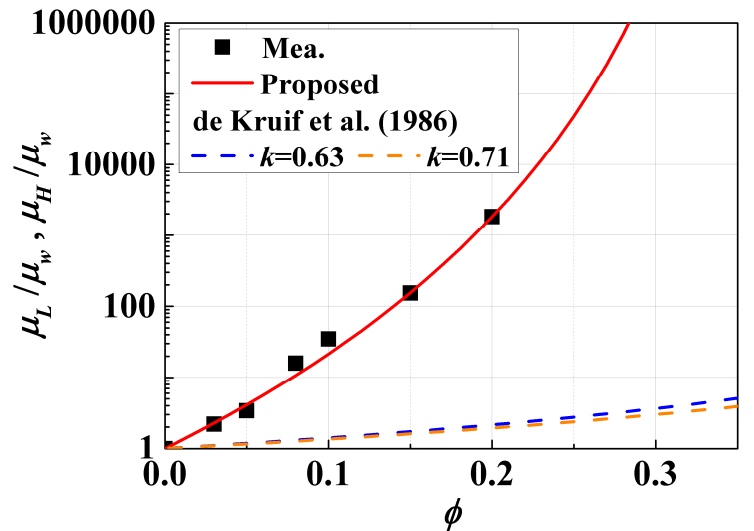

図-10 浮遊砂濃度 $\phi$ と粘度 $\mu$ の関係

砂濃度 $\phi$ ともに (4)との対応も確認できる.

最後に, 以上の結果に基づいて式(3)の 行う. 表-2に示した浮遊砂濃度 $\phi$ と低せん断ニュートン粘 度 $\mu$ の值に対して最小自乗法を適用したところ，

$$
\mu_{L}=\mu_{w}\left(1-\frac{\phi}{0.379}\right)^{-10.0}
$$

を得た。この結果を図-10に示す。ただし， 印は表-2 を，実線は式(8)を表す。また，シリカを含むシクロへキ サンの懸濁液に対するde Kruif ${ }^{10)} の$ 結果も参考のため に破線で示した. ここで， $k=0.71$ は低せん断ニュートン 粘度 $\mu$ に対する結果, $k=0.63$ は高せん断二ュートン粘度 $\mu \mathrm{H}$ に対する結果である. 図-10より，表-2で同定した低 せん断ニュートン粘度 るものの，式(8)で概ね評価できていることが分かる．ま

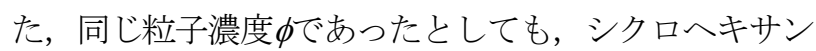
とシリカの懸濁液の $\mu$ （橙破線） と比較して水と粘土の 懸濁液の $\mu$ の方が極めて大きいことが分かる.

以上より, 浮遊砂濃度 $\phi$ 引゙与えられれば式(8)より低せ 几断ニュートン粘度 られれば $\mu$, $\mu_{H}(=1.00 \mathrm{mPa} \cdot \mathrm{s}), n(=2), \tau_{c}(=80 \mathrm{mPa})$ を 代入した式(5)より粘度 $\mu$ が求められることから, 浮遊砂 濃度 $\phi$ とせん断応力脰与えられれば粘度 $\mu$ が決定できる ことが分かる。したがって，従来のように浮遊砂濃度依 存性だけではなく, せん断応力依存性も考慮した上で粘 度 $\mu$ の評価を行えるようになったと言える。また，図-4 から図-9より浮遊砂を含む懸濁液の粘度 $\mu$ はせん断応力 $\tau$ の大小によらず水の粘度よりも大きく, 濁水状態の津波 の流動場は清水状態のそれとは異なる可能性が示唆され

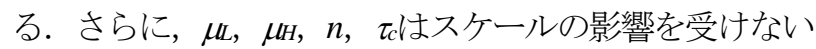
一方で，せん断応力 $れ は \mathrm{ML}^{-1} \mathrm{~T}^{-2}$ の次元を有し，スケール の影響を受けることが分かる．つまり，例えば実現象と それをFroudeの相似則に基づいてLの次元を $1 / N_{L} し た$ 水 理実験を考えると，水理実験のせん断応力は実現象と比 較して $1 / N_{L}$ と小さく，水理実験の浮遊砂濃度として実現
象と同じ值を用いると，粘度の増加の影響を過大評価し てしまうと言える.したがって，津波の流動場に与える 浮遊砂濃度の影響を実験的に検討する際における浮遊砂 濃度の設定の重要性が示唆される.

\section{5. 結論}

濁水状態の津波・海岸保全施設本体の挙動・基礎地盤 の洗掘等の地形変化・基礎地盤の支持力の4者間の相互作 用を解析できる数值計算モデルの構築に向けた基礎的な 研究として，本研究では浮遊砂を含むことによる粘度の 変化を取り扱い，その評価式のパラメータの同定を粘度 計を用いた実験により行った。その結果，浮遊砂を含ま ない清水状態のとき，粘度 一定值をとっており，ニュートン流体であることを確認 した，その一方で，浮遊砂を含んだ蜀水状態のとき，粘 度 $\mu$ はせん断応力 $\tau の$ 増加とともに減少し，非ニュートン 流体となることを確認した。また，浮遊砂濃度 $\phi$ とせん 断応力脰与えられれば，式(8)と高せん断ニュートン粘 度 $\mu_{H}(=1.00 \mathrm{mPa} \cdot \mathrm{s}), n(=2), \tau_{c}(=80 \mathrm{mPa})$ を代入した式(5) により粘度 $\mu$ が推定できることを示した。

ただし，第2ニュートン領域の計測ができなかったこ とから高せん断二ュートン粘度 $\mu H$ の同定に， $\tau_{c}$ は粒子の 粒径 $a$ と絶対温度 $T$ 関数であるものの，カオリンを含む $20{ }^{\circ} \mathrm{C}$ 懸濁液に限られた条件であることから また第2章の冒頭で述べたように粘度は粒子を構成する 鉱物に依存することから，鉱物種が粘度に与える影響に 対する検討に課題を残している．また，実際の津波にお

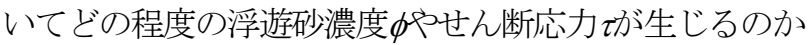
情報がなく，またそれに対する数值解析等も行っていな いことから，浮遊砂を含むことで津波の流動場や津波に よる波圧や波力がどの程度変化するのかを検討するまで には到っていない．以上を含め数多くの課題を残してい ることから，今後も継続して検討していく所存である.

謝辞 : 本研究は, 科学研究費補助金若手研究(B)（代表者 : 中村友昭 ; 課題番号 : 26820200）の補助を受けたことを 付記し，謝意を表する.

\section{参考文献}

1) Vanoni, V. A.: Transportation of suspended sediment by water, Trans. ASCE, Vol. 111, pp. 67-133, 1946.

2) 日野幹雄: 固体粒子を浮遊した流れの乱流構造の変化, 土木学会論文集，第 92 巻，pp. 11-20，1963.

3) Itakura, T. and Kishi, T.: Open channel flow with suspended sediments, Proc. ASCE, Vol. 106, HY8, pp. 1325-1343, 1980.

4) 中川博次, 辻本哲郎: 移動床流れの水理, 技報堂出版, 
310 p., 1986.

5) Mehta, A. J.: An Introduction to Hydraulics of Fine Sediment Transport, Advanced Series on Ocean Eng. Vol. 38, World Scientific, 1060 p., 2013.

6) Einstein, A.: Über die von der molekularkinetischen Theorie der Wärme geforderte Bewegung von in ruhenden Flüssigkeiten suspendierten Teilchen, Ann. Physik, Vol. 17, pp. 549-560, 1905.

7) Bathchelor, G. K.: The effect of Brownian motion on the bulk stress in a suspension of spherical particles, J. Fluid Mech., Vol. 83, No. 1, pp. 97-117, 1977.

8) Krieger, I. M. and Dougherty, T. J.: A mechanism for non-Newtonian flow in suspensions of rigid spheres, Trans.
Soc. Rheology, Vol. 3, pp. 137-152, 1959.

9) 粉体工学会 : 液相中の粒子分散・凝集と分離操作，粉 体工学叢書第 4 巻, 日刊工業新聞社, 240 p., 2010.

10) de Kruif, C. G., van Iersel, E. M. F., Vrij, A., and Russel, W. B.: Hard sphere colloidal dispersions: viscosity as a function of shear rate and volume fraction, J. Chem. Phys., Vol. 83, No. 9, pp. 4717-4725, 1985.

11) Russel, W. B., Saville, D. A., and Schowalter, W. R.: Colloidal Dispersions, Cambridge Univ. Press, 544 p., 1992.

12) Krone, R. B.: A study of rheological properties of estuarial sediments, Technical Bulletin No. 7, Committee on Tidal Hydraulics, U. S. Army Corps of Engineers, 91 p., 1963.

\title{
MEASUREMENT AND EVALUATION OF VISCOSITY OF FLUID CONTAINING HIGHLY-CONCENTRATED SUSPENDED SEDIMENT
}

\author{
Tomoaki NAKAMURA, Manami SUZUKI and Norimi MIZUTANI
}

As a fundamental study for establishing numerical analysis technology that can compute dynamic interactions between tsunamis containing suspended sediment, behavior of coastal protection facilities, seabed profile change such as local scouring, and seabed response, parameters of an evaluation equation for the viscosity of a fluid containing suspended sediment were identified from laboratory experiments using a viscometer. It was confirmed that while clear water was a Newtonian fluid because its viscosity was independent on the shear stress, muddy water containing suspended sediment was a non-Newtonian fluid because its viscosity decreased with an increase in the shear stress. Furthermore, it was found that once suspended sediment concentration and shear stress are given, the viscosity of the muddy water can be determined from the evaluation equation using the identified parameters. 